\title{
SOCIOECONOMIC DETERMINANTS OF RURAL HOUSEHOLDS' FOOD CROP PRODUCTION IN OGUN STATE, NIGERIA
}

\author{
OMotoso, A. B. ${ }^{1}$ - DAUD, A. S. ${ }^{2}-$ AdEBAYO, R. A. ${ }^{3}$ - OMOTAYO, A. O. ${ }^{4 *}$ \\ ${ }^{I}$ Department of Cooperative Economics and Management, Oyo State College of Agriculture and \\ Technology, P. M. B. 10, Igboora, Nigeria \\ ${ }^{2}$ Department of Agricultural Extension and Management, Oyo State College of Agriculture and \\ Technology, P. M. B. 10, Igboora, Nigeria \\ ${ }^{3}$ Department of Crop Science, Faculty of Natural and Agricultural Science, North West \\ University, Mafikeng, South Africa \\ ${ }^{4}$ Indigenous Knowledge System Centre, Food Security and Safety Niche, Faculty of Natural and \\ Agricultural Science, North West University, Mafikeng Campus, Mmabatho 2735, South Africa \\ *Corresponding author \\ e-mail: omotayoabiodun777@gmail.com \\ (Received 26 ${ }^{\text {th }}$ Mar 2018; accepted $25^{\text {th }}$ May 2018)
}

\begin{abstract}
Agricultural production seems to hold the key to economic growth and development in the developing nations of the world. The study focused on the socioeconomic determinants of rural household's arable crop production in Ogun State, Nigeria. The specific objectives of this study were to estimate the gross margin of the farmers and determine the effect of their gender resource on food crop production in the study area. Multistage sampling technique was employed to select 210 respondents as population of the study. Budgetary analysis was used to determine their profit margin while Tobit regression analysis was modeled to determine the effect of household's gender resource(s) on food crop output. The result shows that $54.30 \%$ of the respondents have no formal education, $66.7 \%$ male and an average household size of 7 persons. Also, a mean age of 51 years and an average farm size of 9 hectares were derived in the study. Furthermore, the budgetary result revealed that food crop production is profitable with Gross margin of $205107.20 /$ ha $(\$ 564.457 / \mathrm{ha})$. Tobit regression result shows among others that gender of the household's head has a significant influence on output of the farm $(\mathrm{P}<0.05)$. The study therefore recommended the provision of labour saving techniques to encourage female farmers in agricultural production in the study area.
\end{abstract}

Keywords: gender resource, gross margin, socioeconomics, Tobit regression

\section{Introduction}

The improvement in agricultural production is a result of more efficient use of the factors or production, viz physical, socio-economic, institutional and technological. The role of agriculture in economic development of most countries can hardly be overemphasized, the contribution of agricultural growth to overall poverty reduction has been documented (Sarris, 2005). A retrospective look into the Nigerian economy and its development reveals that agriculture was both the main stay of the Nigerian economy and the chief foreign exchange earner (Nwaiwu et al., 2017). In the 1960s, agriculture accounted for well over $80 \%$ of the export earnings and employment; about $65 \%$ of the GDP (gross domestic product) and about $50 \%$ of the government revenue (FRN, 2000). This contribution to the Nigerian economic growth has however declined over the years.

The contribution of agriculture to the GDP was about 50\% in 1970 and $34 \%$ in 2003 (CBN, 2003). Although agriculture no longer serves as the leading contributor to 
Nigeria's gross national product and leading foreign exchange earner due to phenomenal growth in the petroleum sector of the economy, agriculture is still the dominant economic activity in terms of employment and linkages with the rest of the economy (Adebile and Amusan, 2011). The principal constraint to the growth of the agricultural sector is the fact that the structure and method of production have remained the same since independence more than four decades ago (Ukeje, 2005). The United Nations Food and Agriculture Organization rate the productivity of Nigeria's farmland as low to medium - but with medium to good productivity if properly managed (Parukayo and Umaru, 2012). To be effective, and attain higher level of productivity and growth in the agricultural sector there is a need to identify the major factors that determine its growth.

Agricultural production thus seems to hold the key to economic growth and development in developing countries. It is expected to stimulate increased crop production and growth into marketable surpluses, improve income earnings and employment opportunities, and enhance nutritional status, health care and household welfare in general. It is also expected to create changes in gender roles, imbalances within the household and a shift in the allocation of the resources available within the household. These changes will affect males and females differently in terms of costs and benefits generated and the efficient utilization of the household Resources. This necessitates the need for the incorporation of gender perspectives into development programmes. This is because gender related differences are expected to influence activity diversification and income generation in the household.

\section{Problem statement}

Farming activities in tropical Africa has always been dominated by rural women who grow a substantial amount of the staple foods, yet, they still have much less access to knowledge, technology, credit and land than their male counterpart (Adewumi and Omotesho, 2002). African women on small scale rain-fed farms produce up to 70-80\% of the domestic food supply in most sub-Saharan African societies (WHO, 2003). On average, they also provide $46 \%$ of the agricultural labour. However, women's yields are too low by Green Revolution Standards ( 3 to 4 tonnes per hectare for food grains), and much lower than men's yields in societies where a comparison can be made (for example, where men grow the same crops on different fields or where yields of female headed households can be compared to those of male headed households).

Gender differences in productivity have been shown to be due to differences in the intensity of use of productive inputs (such as fertilizer, manure, land and labour, credit, extension training, and education) rather than in differences in the efficiency or management styles of men and women (Ganiyu and Omotayo, 2017). Because rural farmers faced problem of cash and/or credit to acquire modern yield-increasing inputs of production, they tend to produce less, and more of their crops are consumed within the family (Rahji, 2007). In Nigeria, the Structural Adjustment Programme (SAP) also tended to disproportionately burden women. The removal of subsidies, which have caused a rise in input prices, and liberalization measures, which have resulted in a flood of cheap imports, have further harmed local food producers, especially women farmers (Rahji, 2007).

Estimates by (Ukeje, 2005), show that if productive inputs like fertilizer, manure and labour could only be reallocated within the African household in some societies the results could mean an increase in the value of household output in the range of 10-20\%. 
In response to the widespread gender disparity in terms of access to farm credit and technical logistics in rice production, the government of Nigeria has introduced progender special crop interventions like block farms. In view of the above problems, this research will try to find answer to the following research questions such as how do we measure the gender impact of household resource allocation on agricultural production and what is the gross margin of food crop farmers in the study area?

\section{Objective of the study}

The general objective of the study is socioeconomic determinant of household food crop production in Ogun State, Nigeria. The specific objectives of the study are to:

1. Describe socio-economic characteristics of food crop farmers in Ogun State, Nigeria

2. Estimate profitability of food crop farmers in the study area

3. Determine the effect of household gender resource on food crop production

\section{Hypothesis of the study}

The hypothesis of the study stated in null form:

$\mathrm{HO}_{1}$ : There is no significant difference between female farming hour and male farming hour in agricultural production in Ogun state.

\section{Materials and methods}

\section{Methodology}

The study was carried out in Ogun State in South Western Nigeria because of her agricultural production pedigree. Ogun state is located in the south-west corner of Nigeria and was created in 1976 by the then Federal Military Government from the old western region (Fig. 1). It is neighboured by Oyo, Ondo, Lagos, Edo and Delta States. It is situated within the tropics and derives its name from the big "River Ogun". The state lies between $7^{\circ} 01^{\prime}$ and $7^{\circ} 18^{\prime} \mathrm{N}$ and between $2^{\circ} 2^{\prime}$ and $3^{\circ} 55^{\prime} \mathrm{E}$. It has a tropical climate with rainforest vegetation on its southern part and a derived savannah on its northern end. It has an estimated land area of $16,409.26 \mathrm{~km}^{2}$. The estimated human population is $3,751,140$ (2006 population census) and it is characterized commercially by a dual economic focus, the bourgeoning industrial sector and a dominant agricultural sector. The study populations were mainly rural farming households who engaged in food crop production in the study area.

\section{Sampling procedure and sample size}

Sampling technique for this study was based on the four Agricultural zones by the Ogun state Agricultural Development Programme (OGADEP). These are Abeokuta, Ikenne, Ilaro and ijebu zones. Multistage random sampling technique was employed to select a total of 210 farming household in the study area. First stage involved the random selection of two zones which are Abeokuta and Ilaro. Second stage involved random selection of three (3) and two (2) blocks from each of the two ADP zones respectively. Stage three involved a random selection of four (4) cells from each of the blocks. While the last stage involved random selection of eleven (11) farming households from each of the cells. But a total of 210 sampled data were used for this 
study. Primary data were collected in 2014 from food crop farmers using structured questionnaire and interview schedule. Data were analysed by frequency count, percentage, mean, budgetary and Tobit regression analysis using Stata 11.

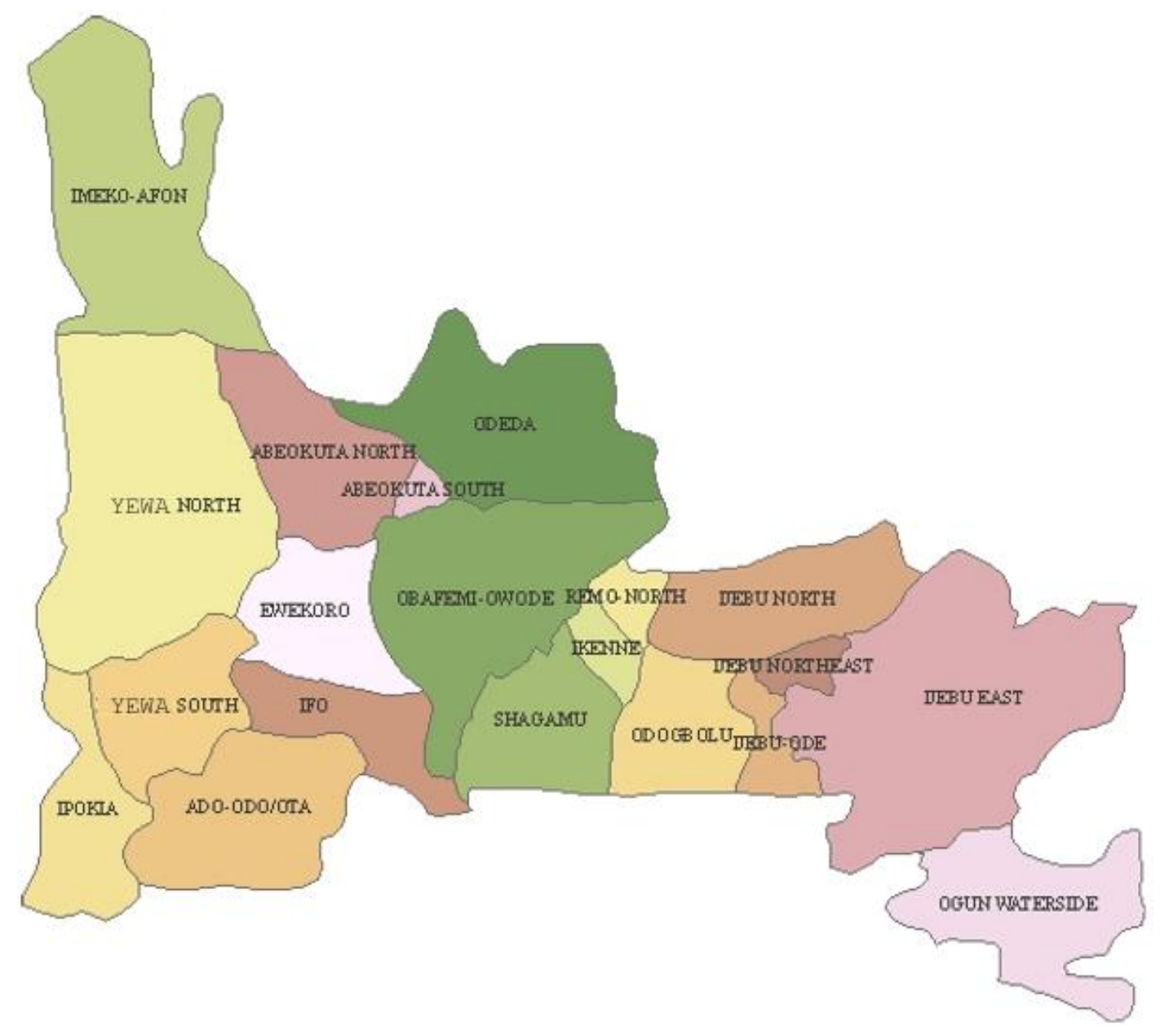

Figure 1. Map of Ogun State showing local government areas

\section{Results and discussion}

\section{Socioeconomic characteristics of respondents}

Socioeconomic factors of the respondents comprise of personal attributes of the respondents are presented in Table 1. Majorities (66.7\%) of the respondents are male and $33.3 \%$ are female. In addition, majority $(55.2 \%)$ of the respondents were married, this indicates that the respondents are adults and people who have mature orientation of life. Also, $4.8 \%$ of the respondents were single and about $30.0 \%$ of them had no formal education. This is quite a large proportion in this century as the implication of these results could be that higher number educational year is known to have a positive influence on the ability of the farmers (Omotayo, 2016). The household size as shown in Table 1 revealed that $1.0 \%$ have household size that is less than $3,46.6 \%$ of the respondents have household size that is less than $7,49.5 \%$ of the rural farmers have household size that is greater than 6 and $2.9 \%$ of the rural farmers have household that is greater than 10. This is support of the findings of (Adelekan and Omotayo, 2017). 
Also, the duration of years spent on farming indicated that $22.9 \%$ have spent between 110 years in farming with mean farming experience of 23 years. Majority $(54.3 \%)$ of the respondents rural reported that their spouse had no formal education, $31.4 \%$ had primary education and $11.4 \%$ had secondary education while $2.9 \%$ of them had tertiary education with mean farm size of 9 hectares.

Table 1. Socioeconomic characteristics of rural food crop farmers. (Source: Field Survey, 2014)

\begin{tabular}{|c|c|c|c|}
\hline Characteristics & Frequency & Percentage & Mean \\
\hline \multicolumn{4}{|l|}{ Age } \\
\hline Less than 30 & 2 & 1 & \multirow{5}{*}{51 years } \\
\hline $30-40$ & 42 & 20.2 & \\
\hline $41-50$ & 70 & 33.6 & \\
\hline $51-60$ & 56 & 26.8 & \\
\hline 60 above & 40 & 19.4 & \\
\hline \multicolumn{4}{|l|}{ Religion } \\
\hline Christianity & 104 & 49.5 & \\
\hline Islam & 106 & 50.5 & \\
\hline \multicolumn{4}{|l|}{ Marital status } \\
\hline Single & 10 & 4.8 & \\
\hline Married & 116 & 55.2 & \\
\hline Divorced & 20 & 9.5 & \\
\hline Widowed & 30 & 14.3 & \\
\hline Separated & 34 & 16.2 & \\
\hline \multicolumn{4}{|l|}{ Educational Level } \\
\hline No formal education & 62 & 29.5 & \\
\hline Primary education & 106 & 50.5 & \\
\hline Secondary education & 34 & 16.2 & \\
\hline Tertiary education & 8 & 3.8 & \\
\hline \multicolumn{4}{|l|}{ Spouse education } \\
\hline No formal education & 114 & 54.3 & \\
\hline Primary education & 66 & 31.4 & \\
\hline Secondary education & 24 & 11.4 & \\
\hline Tertiary education & 6 & 2.9 & \\
\hline \multicolumn{4}{|l|}{ Farming experience } \\
\hline Less than 10 & 48 & 22.9 & \\
\hline Oct-15 & 44 & 21 & \\
\hline $16-20$ & 26 & 12.4 & \\
\hline $21-25$ & 10 & 4.9 & 223 \\
\hline 25 above & 82 & 39.3 & \\
\hline \multicolumn{4}{|l|}{ Farm size } \\
\hline Less than 3 ha & 40 & 19.1 & \\
\hline 3-May & 62 & 29.6 & \\
\hline 6-Sep & 32 & 15.3 & 9 \\
\hline Oct-13 & 24 & 11.5 & \\
\hline 13 above & 52 & 24.8 & \\
\hline
\end{tabular}




\begin{tabular}{c|c|c|c}
\hline Gender & 70 & 33.3 & \\
Male & 140 & 66.7 & \\
Female & 2 & 1 & \\
\hline Total house size & 98 & 46.6 & \\
Less than 3 & 104 & 49.5 & 7 \\
3-Jun & 6 & 2.9 & \\
7-Oct & $\mathbf{2 1 0}$ & $\mathbf{1 0 0}$ & \\
10 above & & & \\
Total &
\end{tabular}

\section{Budgetary analysis of farming households}

The budgetary result for farming system of the farming household in the study area was presented in Table 2. The Total Variable Cost per hectare (TVC/ha) for food crop production such as maize, cassava, vegetable and pepper was estimated at \$77131.80/ha (\$212.268). Furthermore, Labour cost, Transportation cost, cost of planting materials, cost of herbicides, cost of fertilizer and cost of tractor service was accounted for $41.5 \%, 2.1 \%, 5.6 \%, 5.8 \%, 11 \%$ and $34 \%$ of the Total Variable Cost of production, respectively. This implies that labour constituted the larger proportion (42.0\%) of Total Variable Cost of production of food crop farmers in the study area. Furthermore, Total Revenue (TR), Gross Margin (GM) for food crop production were estimated at $\$ 282239.00 /$ ha (\$789.114) and $\$ 205107.20$ /ha (\$564.460) respectively in the study area. This implies that food crop farmers perform better in terms of margin between total revenue and total variable cost of food crop production.

Table 2. Cost-return structure of food crop farmers in the study area. (Source: Field Survey, 2014)

\begin{tabular}{c|c|c}
\hline Variables & Value $(\mathbf{N})$ & $\begin{array}{c}\text { \% of total } \\
\text { variable cost }\end{array}$ \\
\hline Revenue & $122255.00(\$ 336.447)$ & \\
Value of maize & $104654.00(\$ 288.009)$ & \\
Value of cassava & $55330.00(\$ 154.697)$ & \\
Value of other & $\mathbf{2 8 2 2 3 9 . 0 0 ( \$ 7 8 9 . 1 1 4 )}$ & \\
Total revenue & $32037.00(\$ 89.5724)$ & \\
\hline Variable cost items & $1639.80(\$ 4.51275)$ & 2.126 \\
Labour cost $(\mathbf{N})$ & $4290.00(\$ 11.8061)$ & 5.562 \\
Transportation cost & $4454.00(\$ 12.4530)$ & 5.775 \\
Cost of planting materials & $8511.00(\$ 3,044,090)$ & 11.034 \\
Cost of herbicides & $26200.00(\$ 9,370,840)$ & 33.968 \\
Cost of fertilizer & $\mathbf{7 7 1 3 1 . 8 0}(\$ \mathbf{2 1 5 . 6 5 3})$ & \\
Cost of tractor service & $\mathbf{2 0 5 1 0 7 . 2 0}(\$ \mathbf{5 7 3 . 4 6 0})$ & \\
Total variable cost & & \\
Gross margin & & \\
\hline
\end{tabular}




\section{Parameter estimates of the Tobit regression}

Table 3 below showed the result of Tobit regression to determine the effect of explanatory variable on the output of food crop farmers in Ibarapa Central Local Government Area of Oyo State. The Marginal effects of the independent Variables were estimated because they are very important for decision making. Among 14 variables considered in the model, Ten (10) were found to be statistically significant which includes gender, farm size, farm, fertilizer, planting materials and herbicide. All the coefficients have the expected sign. The parameters estimates of the Tobit regression of food crop farmers showed that farm size, fertilizer, hired labour, gender were positively significant at $1 \%$ respectively while male labour hour was positively significant at $5 \%$ confidence level. This implies that $1 \%$ increment in these variables will increase the farmers output by 15.7, 2.8, 0.01, 2.3 and 1.5 respectively. Also, herbicide, female off time and female labour hours were negatively significant to farmers output in the study area at $1 \%$. The implication is that the herbicide was over utilized and female does not really contribute significantly to agricultural production in the study area.

Table 3. Parameter estimates of the Tobit regression. (Source: Field Survey, 2014)

\begin{tabular}{c|c|c|c}
\hline Variables & Coefficient & Standard error & t-value \\
\hline Constant & -66.97913 & 45.05613 & -1.49 \\
Gender $\left(\mathrm{X}_{1}\right)$ & 15.69475 & 1.59054 & $10.08^{* * *}$ \\
Marital status $\left(\mathrm{X}_{2}\right)$ & 1.350062 & 6.245415 & 0.22 \\
Educational level $\left(\mathrm{X}_{3}\right)$ & 6.833226 & 9.187224 & 0.74 \\
Male hour $\left(\mathrm{X}_{4}\right)$ & 1.542199 & 0.7912725 & $1.95^{* *}$ \\
Spouse education $\left(\mathrm{X}_{5}\right)$ & -6.672392 & 8.030902 & -0.83 \\
Farm size $\left(\mathrm{X}_{6}\right)$ & 2.837706 & 0.8978289 & $3.16^{* * *}$ \\
Farm experience $\left(\mathrm{X}_{7}\right)$ & 1.426395 & 1.393604 & 0.24 \\
Fertilizer $\left(\mathrm{X}_{8}\right)$ & 2.75065 & 1.073695 & $2.56^{* * *}$ \\
Planting materials $\left(\mathrm{X}_{9}\right)$ & 0.001723 & 0.000824 & $3.21^{* * *}$ \\
Agrochemicals $\left(\mathrm{X}_{11}\right)$ & -1.924005 & 0.583555 & $-4.14^{* * *}$ \\
Male off time $\left(\mathrm{X}_{11}\right)$ & -2.394674 & 1.930861 & -1.24 \\
Female off $\left(\mathrm{X}_{12}\right)$ & -0.0002051 & 0.0000531 & $-3.39^{* * *}$ \\
Female labour $\left(\mathrm{X}_{13}\right)$ & -3.3124179 & 0.3488113 & $-9.90^{* * *}$ \\
Hired labour $\left(\mathrm{X}_{14}\right)$ & 2.2542008 & 0.0186509 & $8.80^{* * *}$ \\
Diagnostic statistics & & & \\
Pseudo $\mathrm{R} 2$ & 0.6294 & & \\
Log likelihood & -568.49311 & & \\
Chi square & $34.66 * * *$ & & \\
\hline
\end{tabular}

***implies significant at $1 \%, * *$ implies significant at $5 \%$ )

\section{Measurement of mean difference between male labour hour and female labour hour in agricultural production}

The measurement of mean differences between female labour hours and male labour hours was accomplished with the use of t-test of difference of mean and the result is presented in the Table 4. It was based on the hypothesis that there is no significant difference between male labour hours and female labour hours contributing to farming 
output in the study area. The results of the t-test showed that there is a significant difference between the male labour hour and female labour hours. This implies that male contribute more to farming output than their female counterpart in the study area. Therefore, the null hypothesis was rejected. This implies that there exist a variation in their respective contribution to farming output in the study area which was also buttressed by the result of Tobit regression.

Table 4. Mean difference of between male and female farmer's labour hours. (Source: Field Survey, 2014)

\begin{tabular}{c|c|c|c|c|c}
\hline Category & Mean hour & $\begin{array}{c}\text { Standard } \\
\text { deviation }\end{array}$ & Number & t-value & Decision \\
\hline Male labour hours & 6.304541 & 0.9423509 & 105 & 7.6096 & Reject $\mathrm{H}_{\mathrm{O}}$ \\
Female labour hours & 7.647619 & 1.990268 & 105 & & \\
\hline
\end{tabular}

\section{Discussion}

Various empirical works on household contribution on agriculture such as (Omotayo and Oladejo, 2016; Dipeolu et al., 2009; Ukeje, 2005): reported that male respondents are more involved in agricultural production than their female counterpart. This could be due to the nature of the job as well as the laborious nature of the rural agriculture in the study areas. Furthermore, labour constituted the larger proportion (42.0\%) of Total Variable Cost of production of food crop farmers in the study with Total Revenue (TR), Gross Margin (GM) estimated at $\$ 282239.00 /$ ha (\$789.114) and $\$ 205107.20 /$ ha (\$573.460) respectively in the study area. Also, parameters estimates of the Tobit regression of food crop farmers showed that farm size, fertilizer, hired labour, gender were positively significant at $1 \%$ respectively while male labour hour was positively significant at 5\% confidence level. Also, herbicide, female off time and female labour hours were negatively significant to farmers output in the study area at $1 \%$. Ukeje (2005) was in the opinion that food crop output is proportional to gender of the household head, farm size, agrochemical used and labour cost.

\section{Conclusion}

The findings of this study revealed that majority of the farmers are still in their active age, married and are therefore expected to be productive for available resources. Also, food crop production is profitable in the study area. Furthermore, the Tobit regression shows that male contributes more to agricultural production than female in the study area because majority of the female in the study area venture most of their time on household core and agricultural marketing than food crop production. Based on the study findings and conclusions, the following recommendations are made:

1. The research on labour saving techniques for agriculture in the study area should be initiated to as to improve their production.

2. There should be incentive to encourage female farmers in agriculture.

3. Farm expansion policy that will make agricultural land available to households should be made and this will impact positively on food crop production in the study in Ogun state and Nigeria in whole. 


\section{REFERENCES}

[1] Adebile, O. A., Amusan, A. S. (2011): The non-oil sector and the Nigeria economy a case study of cocoa export since 1960. - International Journal of Asian Social Science 1(5): 142-151.

[2] Adelekan, Y. A., Omotayo, A. O. (2017): Linkage between rural non-farm income and agricultural productivity in Nigeria: A Tobit-two-stage least square regression approach. - The Journal of Developing Areas 51(3): 317-333.

[3] Adewumi, M. O., Omotesho, O. A. (2002): An analysis of production objectives of smallscale rural Farming households in Kwara State, Nigeria. - Journal of Rural Development 25: 201-211. http://210.101.116.28/W_files/kiss61/1h601404_pv.pdf (accessed: 2 November, 2017).

[4] Central Bank of Nigeria (2003): Statistical Bulletin. - Central Bank of Nigeria, Abuja.

[5] Dipeolu, A., Philip, B. B., Aiyelaagbe, I. O., Akinbode, S., Adedokun, T. A. (2009): Consumer awareness and willingness to pay for Organic Vegetables in S. Q. Nigeria. Asian Journal of Food and Agro-Industry 10(11): 57-65.

[6] Federal Republic of Nigeria (FRN) (2000): Obasanjo's Economic Direction 1995-2003. Office of the Honorable Minister for Economic Matters, Abuja, Nigeria.

[7] Ganiyu, M. O., Alabi, A. A, Omotayo, A. O. (2017): Cost and return analysis of cassava flour (lafun) production among the women of Osun State. - Science Research 5(5): 7277.

[8] Rahji, A. M. (2007): Gender impacts of farm household resource allocation on agricultural commercialization in Oyo state, Nigeria. - ASSET: An International Journal (Series C) 2(1):1-15.

[9] Nigeria Population Commission (2006): Population census. - Nigeria Population Commission, Abuja.

[10] Nwaiwu, I. U. O., Obasi, P. C., Korie, O. C., Ben-Chendo, N. G., Uhuegbulem, I. J., Anyanwu, F. C. (2017): Effects of household foods on health status of farmersimplication on farm labour productivity in Ahiazu Mbaise Imo State, Nigeria. - FUTO 2(2).

[11] Omotayo, A. O. (2016): Farming households' environment, nutrition and health interplay in Southwest, Nigeria. - International Journal of Scientific Research in Agricultural Sciences 3(3): 84-98.

[12] Omotayo, A. O., Oladejo, A. J. (2016): Profitability of Cassava-based production systems. - Journal of Human Ecology 56(1/2): 196-203.

[13] Purokayo, S. G., Umaru, A. (2012): Global food crisis: Public capital expenditure and agricultural output in Nigeria. - Journal of Food Research 1(1): 286.

[14] Sarris, A. H. (2005): The Role of Agriculture in Economic Development and poverty reduction. An empirical and conceptual Foundation. - Rural Development Department, World Bank.

[15] Ukeje, E. U. (2005): Modernizing small holder agriculture to ensure food security and gender empowerment. - Journal of Issues and Policy 2(4): 142

[16] World Health Organization (WHO) (2003). Diet, nutrition, and the prevention of chronic diseases: report of a joint WHO/FAO expert consultation (Vol. 916). 